\title{
Feminist Art Epistemologies: Understanding Feminist Art
}

\author{
PEG BRAND
}

Feminist art epistemologies (FAEs) greatly aid the understanding of feminist art, particularly when they serve to illuminate the hidden meanings of an artist's intent. The success of parodic imagery produced by feminist artists (feminist visual parodies, FVPs) necessarily depends upon a viewer's recognition of the original work of art created by a male artist and the realization of the parodist's intent to ridicule and satirize. As Brand shows in this essay, such recognition and realization constitute the knowledge of a well-(in)formed FAE. Without it, misinterpretation is possible and viewers fail to experience and enjoy a full and rewarding encounter with a provocative and subversive work of art.

What knowledge informs an intelligent comprehension and appreciation of a feminist work of art such as Wilma de Kooning's Woman Ia? (Figure 1). Does ignorance about a prototype painted by Willem de Kooning, entitled Woman I, affect a viewer's judgment and preclude a fair assessment of the imitation? ${ }^{1}$ If so, how might one go about constructing a workable cognitive framework-a feminist art epistemology (FAE) — to insure an optimal viewing experience, interpretation, and evaluation? This essay seeks to illuminate the structure and function of FAEs — enlightened modes of engaging with feminist art — with particular attention paid to a specific subcategory of women's art known as feminist visual parodies (FVPs).

It is common knowledge that most artistic representations of women have not been created by women. Under discussion are the many types of artworks found primarily in museums, galleries, and private art collections that standard art history texts routinely chronicle and study. Most visual depictions of women are created by men who, no matter how empathetic (if at all), lack direct knowledge 


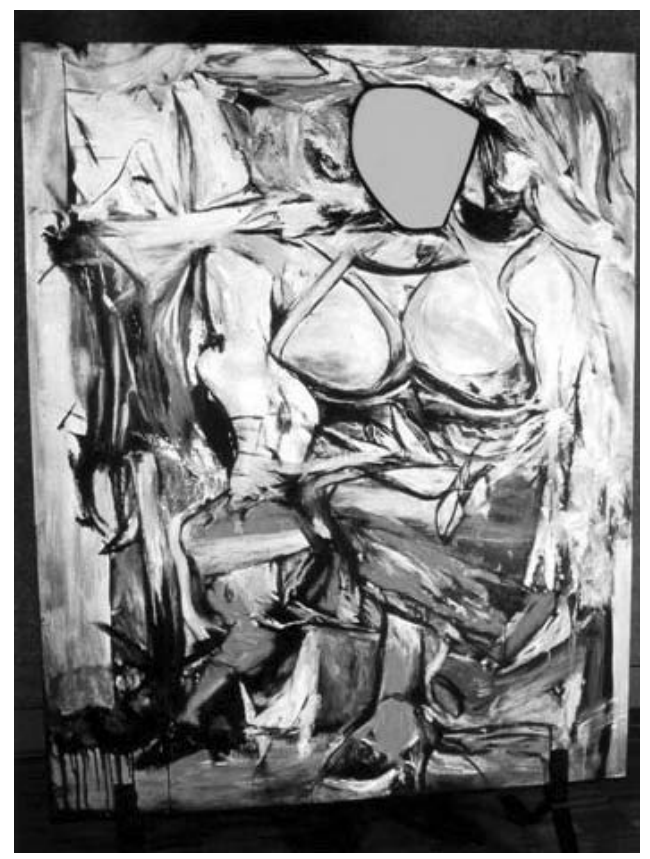

Peg Brand, Wilma de Kooning's Woman Ia (oil on foam board), $473 / 8 \times 593 / 8$ $\times 1 \frac{1}{2}$ in., 1999. Collection of the artist.

of what it is to be a woman. This experiential ignorance has not prevented them, however, from assuming the dominant role of philosophically and pictorially defining the essence of "woman" throughout the ages. Their representations have constituted the predominant, nearly uninterrupted two-thousand-year continuum of historical "masterpieces" known as the artworld canon. ${ }^{2}$

Women who create, however, continue to struggle for legitimacy and respect within mainstream art contexts. Their numbers, historically low in comparison to men, still constitute a minority in today's artworld. Sometimes, the content of their work creates problems as well. Subject matter depicted by women, like that of men, can vary widely. Women have created landscapes, still life, portraiture, and abstraction. But unless the style or name of the artist is easily recognizable (consider a work quickly identified as "a Picasso"), an art viewer is generally ignorant as to the identity and sex of the artist. This can sometimes diminish a viewer's experience; it often motivates a desire to know more about the artist, including specific biographical information.

Feminist art can provide aesthetic experiences even more pleasurable than standard (nonfeminist) art, once such knowledge is learned. Feminist works are often identifiable by their female-centered subject matter, informed by a strong familiarity with and empathy for women's lived experiences. Women or men can create them, but typically, they are the result of a woman's hand 
and are informed by a particular cognitive makeup, a positive, supportive, pro-female ideology that reinforces a woman's integrity, strength, autonomy, freedom, and self-empowerment. An FAE is a shorthand way of capturing the conceptual framework that an artist embodies in her artwork or a viewer brings to the art to better understand it. An FAE is a body of knowledge that can be perceived, intuited, or learned directly from the work, as well as augmented by sources outside the work. I suggest FAEs not only provide the best way for art viewers to engage feminist art that often requires special knowledge to understand, but also that communal FAEs - information shared by art viewers and artists alike-greatly enhance appreciation by providing the most accurate approximation of the artist's original intent. ${ }^{3}$

Thus both men and women can create art that is considered feminist, but feminist art created by women is a unique expression of personal experiences and firsthand knowledge that seeks to bring attention to women's positive attributes. Feminist art can be enjoyed for its aesthetic features, such as color, shape, balance, and imitation of people and objects found in the real world, but it can also be appreciated for its nonaesthetic features, such as content and contextual meaning within the broader society. Thus feminist art can be considered a type of political art; in fact, well-known art critic and theorist Lucy R. Lippard unapologetically called it "propaganda" (Lippard 1976). The message of feminist art is twofold: first, a challenge to the well-known historical tradition of depictions of women by which male artists stereotype them as purely sexual, passive, and dependent; and second, the promotion of positive feminine attributes, accomplishments, and autonomy. Feminist visual parodies constitute one specialized genre meant to subvert sexist stereotypes; they are often recognized for their deliberate use of humor. How do FAEs operate within this specific context of FVPs and what political strategies of undermining oppression are such artworks designed to encourage? This essay aims to address these questions.

To set the stage, I provide some background information from today's artworld in order to demonstrate the need for FAEs in understanding current feminist art. The first section provides a picture of the sociological and theoretical makeup of an artworld that shows men tightly controlling the power that serves to valorize male artists routinely, perpetuate sexist institutions of representation and education, and maintain ignorance about women and their art. In spite of feminist challenges to the marginalization of their work over the past decades, it is still difficult for feminist art to achieve recognition and respect on par with men's, especially given a resurgence of the culture wars and a growing vocal opposition to feminist ideology (see the second section of this essay below). Higher numbers of women in art schools and in the artworld do not necessarily result in greater opportunities for exhibitions or more accolades. At times, it seems as if there is a concerted and conscious effort to prevent women 
from parity. The third section of this essay builds upon our familiarization with today's artworld and proceeds to an analysis of several examples of FVPs in order to flesh out the substance of FAEs and their helpful role in combating ignorance about women's identity, intentions, and achievements. I argue that increasing one's knowledge about feminist art serves to recognize the voice of women who are on the front lines of the political battle to promote a more positive message about women. Such acknowledgment serves to show support for the valuable contribution made by women in the arts.

\section{Men Rule: Domination of the Artworld, Institutionalized Knowledge, and IgnORAnCe}

Gender discrimination, that is, intentionally marginalizing women in the artworld and maintaining ignorance about women's creative work, has long been operative in an artworld intent on maintaining the status quo. Throughout the history of art, certain artworks have been canonized into a list of wellknown examples called "masterpieces" - with very few exceptions. ${ }^{4}$ Historically speaking, this is somewhat understandable, given that women were severely circumscribed by social constraints against careers and routinely deterred from aspirations toward art. Denied education and training, they were not only discouraged from pursuing creative goals but also barred from important circles of critical discourse that rewarded artworks with value and renown. ${ }^{5}$ But what about more recent times, for example, the latter part of the twentieth century and now, in the new millennium? Do women fare better in terms of education, exhibition opportunities, and media coverage? Are feminist artworks, specifically, judged fairly and occasionally admired by the artworld?

To answer these questions, it is necessary to look at the content of art produced by contemporary male and female artists and, in particular, how images in art reflect deeper meanings that belie popularly held views and opinions. For instance, many revered works of art are not only created by men but portray men very differently from women. ${ }^{6}$ Where men in art are often pictured as active, intelligent, strong, virtuous, spiritually superior, good leaders, and excellent role models, women are often depicted in terms of lack: of motivation, control, brainpower, talents, or moral virtue. In spite of being portrayed as beautiful—presumably a compliment to their natural features and by extension, inner character-such depiction also provides ample opportunity to present conflicting characterizations, and in fact, an overall negative opinion. Sometimes portrayed as merely weak, passive, inferior, purely physical or sexual in nature (and hence, rather impotent and harmless), women can also be simultaneously cast as the embodiment of uncontrollable lust, power, and a threat to man. Invoking the biblical Eve as the paradigm of temptation, all women are seen to epitomize oversexualized danger intent on eroding man's sound reasoning. They are the cause of all sin 
(for all of mankind!) committed by "innocent" men who are seduced by female wiles. Throughout the centuries, innumerable male artists, writers, politicians, and philosophers have encountered few barriers to postulating theories about women's inferiority, irrationality, and immorality. ${ }^{7}$ It appears to be the case that artists, scholars, and the powerful patriarchy long in charge of social hierarchies and opportunities, succeeded in orchestrating a sociohistorical context that established an institutionalized bias against women. By denying them education, training, and other creative outlets, women's achievements have been minimized and marginalized. This perpetuation of ignorance and denial of opportunity has served to maintain men's power over women in the realms of politics, economics, religion, philosophy, science, and literature-as well as art.

The dominance of men and of sexist thinking within the artworld is clearly enhanced by the prolific writings by numerous and influential male theorists, critics, aestheticians, and philosophers of art. Not only have men controlled the visual representation of women (and by "visual" here I generally mean painting, sculpture, drawing, and printmaking), but the recorded affirmations of the legitimacy of men's portrayals of women fill volumes of influential texts and catalogs. As a result, the standard academic study of the history of art unequivocally showcases male artists. Only since the consciousness-raising 1970s - with the advent of the feminist movement in the United States and the United Kingdom - have the internal machinations of this power structure been exposed and critiqued. For the first time within the academic discipline of art history, scholars began to discover women artists of the past, some of whom made a successful living from their art and surpassed their male counterparts in esteem, sales, and commissions. Still, there are college-level art programs that fail to incorporate into the curriculum adequate scholarship on these women and there are faculty who subtly teach students that genius is the unique province of men, thereby relegating women to second-class creators. In philosophical circles, some faculty still resist the inclusion of a feminist point of view in their aesthetics texts and classes. When men dominate the creative realm, the discourse about art, and the pedagogy that influences succeeding generations, it is inevitable that a system of aesthetic evaluation that privileges male creativity, originality, and attendant critical reasoning skills serves to maintain the status quo of patriarchal dominance. ${ }^{8}$

It can be equally unsettling to discover power inequities outside the academy as well. Women's voices have grown stronger within the contemporary artworld but they continue to be underrepresented, given their numbers. Feminist art, in particular, is even less well received than women's works generally, since it is often designed to provoke and undermine the prevailing power structure. I invoke below several examples by feminist artists Judy Chicago and Renée Cox to demonstrate the point, but first, for context, a quick overview of the way contemporary critics favor male artists in journalistic print. 
A brief look at journalistic coverage illustrates what I believe is the continuing domination of the artworld by those who utilize effective strategies to insure ignorance about women's work. Consider one arbitrarily chosen issue of the New York Times and its coverage of four artists (March 21, 2004). Along with prominent monthly art magazines such as Art in America, Artforum, and ArtNews, art reviews in the New York Times constitute an important source of information within the artworld. On the day in question, three of the four artists were male. This ratio alone fails to reflect a realistic difference in numbers of artists since it is the case that more than 50 percent of art students in the United States are women. They graduate in higher numbers than men, but ultimately their numbers decline and their activity diminishes—a phenomenon that is caused by fewer exhibition opportunities and media coverage, which in turn produces even fewer such opportunities. A quick glance at any list of gallery exhibitions in New York or any major city with an adequate art scene indicates that women are accorded fewer exhibitions than men, particularly the all-important, career-defining one-person show. ${ }^{9}$

Women's art is minimized in other ways as well. All three male artists had color reproductions accompanying their text; a male artist was chosen to be pictured alongside his work; and a male artist was lucky enough to be featured in the Magazine section with a four-page spread. All four critics cited past "masters" or contemporary male cohorts-a total of eighteen artists, architects, writers, and even philosophers- to elevate the status of the lesser-known artist's work, thereby lending credibility to his or her reputation. ${ }^{10}$ No woman is ever cited to enhance the value of the art under discussion, even in the case of the review of the lone woman; rather, like the male artists, she was compared to male counterparts. ${ }^{11}$ Finally, the authors' choices of words reveal a bias that serves subtly to undermine the value of the woman's work. Whereas the authors routinely characterize the men's work in terms of emphasis and strength with words like "eye-popping," and phrases like "a pop-culture event" and "its popularity almost transcending logic" (Kimmelman 2004), they describe the woman's as "charming" and compare it to a patchwork quilt (Bard 2004). Men's work is cast in terms of its popularity and renown; the woman's work in a minimizing way, in terms of the hushed tones of the gallery space. In this particular example, the critic of the female artist is a woman, but it not unusual to find female art critics trained or practiced in writing in a male-biased way, particularly if they are conforming to the standard style for publications within a particular media outlet.

These differences in tone and characterization are troubling indicators of trends in art writing that routinely valorize the work of male artists and minimize that of women. Many other examples could be cited. Michael Kimmelman is notorious for valorizing the young painter John Currin, who is known for his 1990s "licentious and misogynous . . . fixation with female breasts," and whom 
Kimmelman described as "a kind of burlesque, combining bosomy nudes reminiscent of Playboy illustrations with theatrical nods to the old masters/calendar pinups/nude blondes with absurd cantaloupe-like breasts" (Kimmelman 2003). Deborah Solomon confirms the artworld's approval, citing Currin as "one of his generation's most esteemed painters" (Solomon 2003). This hyperbole continues a trend already established with other artists, such as David Salle, Gerhard Richter, Jeff Koons, Eric Fischl, Francis Picabia, and Mel Remos, who are repeatedly hyped and promoted for work that borrows heavily from pornography. ${ }^{12}$ Typical of Kimmelman's power to populate the male art hierarchy, the work of video artist Matthew Barney was lauded as "unspeakably beautiful."13 With a critic like Kimmelman in your court, there is no telling how far an art star can go-if he is a man.

Most recently, one writer for the New York Times boldly offered the "X Factor" as the reason for the blatant inequalities in the monetary value placed on women's works. Contrasting the paintings of Lee Krasner, up for auction in May of 2005 at Christie's for $\$ 500,000$ to $\$ 700,000$ with those of Franz Kline, valued at an estimated $\$ 4$ million to $\$ 6$ million, Greg Allen cites statistics that belie a continuing imbalance of fortunes: "Of the 861 works that Christie's, Sotheby's and Phillips de Pury \& Company are offering over three days starting May 10, a mere 13 percent are by female artists. Sixty-one pieces have each been assigned an estimated price of $\$ 1$ million or more; of those, only 6 are by women" (Allen 2005). One art historian cites a glass ceiling; one (female) artist suggests a difference in subject matter; but the author blames a weak exhibition record for women plus the added difficulty of networking in a male-dominated field for the resultant "male-female price gap" and women's failure to establish a strong base of collectors. When it comes to price-the bottom line in the business world-Allen concludes, "the comparison is unmistakable: art made by women is regarded less highly than art made by men . . . because it is made by women." The disparity is not only representative of more general trends in society but astonishingly extreme: "As in almost every other field where money changes hands in society, women's production has been and continues to be valued below that of men, except in this field, the difference is sometimes tenfold or more."14

Adding to the complex factors responsible for the low value of women's art is the fact that art collecting, in the past and for the foreseeable future, remains a male-dominated activity. One observer-the president and chief operating officer of a company investing $\$ 100$ million in art—asks whether the future might improve if women would simply buy more art by women. When projected sales for the year 2006 include Botox (in the United States alone) reaching $\$ 1$ billion a year and drugs and cosmetics for aging baby boomers reaching $\$ 41.9$ billion a year, one can only wonder how much disposable income might be spent by 
women on women's art if they so chose..$^{15}$ Raising the awareness level of women purchasers to the possibility of buying such art could prove undeniably valuable in adding importance to women's work. And one activist band of rebels is intent on doing just that.

\section{Women Rebel: Challenges to the Male-Dominated Artworld that Build FAEs}

One group has notoriously sought to fight ignorance about women's art as women still struggle for gallery representation and exposure within museum shows. Beginning in 1985, artworld inequities began to be publicized by means of entertaining posters freely circulated around New York City that a group known as the Guerilla Girls created. In one poster (Figure 2), they depicted the unusually high number of women in a Whitney Museum Biennial exhibition in 1993, a controversial show nearly unanimously denounced by art critics at the time. As their comments below the chart indicate, the status quo-namely, the predominance of white male artists — was quickly restored with the succeeding 1995 biennial.

\section{TRADITIONAL VALUES AND QUALITY RETURN TO THE WHITEY MUSEUM.}

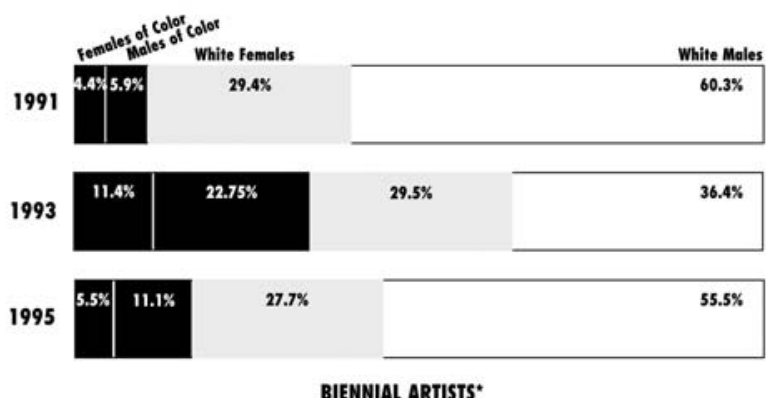

GUERRILLA GIRLS conscherce of twe armorio A pubuc strvice messace from GUERRILA GIRLS CONSCIEMCE OF the ARTWORLD

Guerrilla Girls, The Whitney Museum Gets a New Name, Copyright (C) 1995. 


\section{WHITE WOMEN, 1 WOMAN OF COLOR AND NO MEN OF COLOR - OUT OF 71 ARTISTS?}

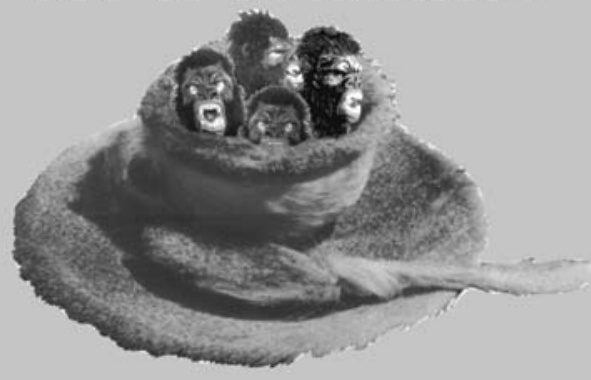

Dear Margit:

We're thrilled that you have managed to redefine the still life to exclude women and artists of color from the practice.

Guerrilla Girls think you should change the Margit Rowell show's title from "Objects of Desire: the The Museum of Modern Art

Modern Still Life" to "The Objects of

MOMA's Desire are Still White Males."

Lotsa luck,

\section{Guerrilia Giris}

Guerrilla Girls, 3 White Women, . . Copyright (c) 1997. 
Similarly, in 1997, the Guerilla Girls created another poster (Figure 3) objecting to the imbalanced gender and racial mix of artists included in a show at the Museum of Modern Art entitled, "Objects of Desire: The Modern Still Life" (the show was, ironically, curated by a woman).

These feminists use wit, humor, stealth, anonymity, in-your-face confrontation, and cheap reproductions to function as the self-proclaimed "conscience of culture." They have produced over one hundred posters in the past twenty years. ${ }^{16}$ Always anonymous and adopting names of dead women artists like Kathe Kollwitz and Frida Kahlo, they have published books, sold T-shirts, and distributed information on gender and racial inequities in the worlds of art, theater, film, politics, and the culture at large. The Girls always appear in public wearing gorilla masks (to focus on the issues rather than their personalities) and use humor "to convey information, provoke discussion, and show that feminists can be funny." They book tours and appearances across the country, and proudly proclaim they have been engaged in "reinventing the ' $\mathrm{F}$ word'-feminism." Comparing themselves to "the mostly male tradition of anonymous do-gooders like Robin Hood, Batman, and the Lone Ranger," they have been known to ask pointed questions that beg for answers. For example, in their latest publication on art museums they ask, "Why do they blow a fortune on a single painting by a white male genius when they could acquire hundreds of great works by women and people of color instead?" (Guerrilla Girls 2004, 3).

Within this pro-female context of support, and in stark contrast to male artists who openly and proudly invoke pornographic depictions of women within the artworld hierarchy, consider the stories of two specific (named) rebels who, in their attempts to redefine 'woman' in a more nuanced exploration of female identity, have experienced not only critical marginalization within the artworld, but also public denouncements and censorship. These examples show the challenges faced by women who have fought against the male art establishment with its continued effort to perpetuate ignorance about women's strength and spirit. Artworld disapproval of their work is particularly acute, perhaps because they have chosen to use the female body in ways intended to empower other women.

One example is pioneering feminist artist Judy Chicago. Chicago is best known for her 1974-1979 creation, The Dinner Party—a collaborative, multimedia installation still visible today that celebrates the symbolic history of women in Western civilization through a series of thirty-nine place settings, set on a triangular banquet table each side of which measures forty-eight feet. ${ }^{17}$ This work is monumental in scope and revolutionary in spirit, motivated by the early 1970 s fervor for recognizing women's past accomplishments. The place settings are historically arranged on three sides of the table: wing one chronicles prehistory to classical Rome; wing two documents the beginning of Christianity to the Reformation; and wing three covers the American Revolution to the women's 
revolution. On the floor below the table are inscribed 999 names of women who, according to Chicago, symbolized "the many thousands of heroic women all over the world who have struggled for freedom and dignity" (Chicago 1996, 1). The artwork consists of numerous media, including ceramics, china painting, embroidery, and other forms of needlework, and each place setting is dedicated to a mythological or real woman of history. Each dinner plate contains a central image labeled "cunt imagery" by Chicago and other women artists. Chicago described this iconic form in 1996: "As l've stated before, although the imagery is rooted in a vulval form, the plates are actually transmuted and layered images. However, I have become convinced that no matter how I describe the plates, this perception of the images as vaginas will continue.... Why this obsession with the plates? Perhaps because they suggest that female sexuality can be assertive, powerful, and transformative" (223). In addition to the iconographic form, the women depicted are equally powerful: goddesses Ishtar and Kali, historic figures like Amazon, Judith, Hypatia, Sappho, Empress Theodora, Saint Bridget, Eleanor of Aquitaine, Trotula (an eleventh-century physician and gynecologist whose treatise on women's diseases was used for 500 years), Hildegarde of Bingen, Christine de Pisan, Queen Elizabeth of England, seventeenth-century painter Artemisia Gentileschi, Native-American guide Sacajawea, Mary Wollstonecraft, Sojourner Truth, Susan B. Anthony, Emily Dickinson, Ethel Smyth, Margaret Sanger, Virginia Woolf, and Georgia O'Keeffe.

A record five thousand people attended the opening of The Dinner Party in 1979 at the San Francisco Museum of Modern Art. Within three months, 100,000 viewers had seen the work in its original venue. Up until its acquisition in 2003 by the Brooklyn Museum of Art, the work had been shown in fourteen venues in a total of six countries and had been seen by over one million people around the world. ${ }^{18}$ When it was first exhibited, it raised the ire of many male art critics, such as Hilton Kramer, as well as political Right-wing and conservative groups. From progressive women it won rave reviews and accolades of identification. The rhetoric of the backlash to its success became evident when Chicago attempted to donate the work to the University of District Columbia in 1990. The consideration of this gift became the cause célèbre of none other than the United States Congress. The budget of the university was controlled by Congress, and in spite of the prior positive vote of the school's trustees to accept the gift, a debate over the merits of The Dinner Party was eventually held on the floor of the U.S. House of Representatives. This is how Judy Chicago conveyed the scene, after a friend phoned to say that her artwork was being discussed-live—on prime time television:

For the next hour and twenty-seven minutes, Donald [Chicago's husband] and I sat stupefied in front of the televised proceedings on C-Span. ... Then-representative Stan Parris from Virginia 
introduced an amendment that would delete $\$ 1.6$ million from the school's operating budget, "in direct response to ... [the] offensiveness to the sensitivities and moral values of our various related communities." He went on to ask, "What kinds of art . . . what value system are we, the Federal lawmakers, responsible for promoting in this, the nation's capital, by being asked to give our imprimatur of approval to this particular work?" $(1996,220)$

Robert Dornan of California proceeded to advance the more damaging charge against the work that was then, according to Chicago, "amplified by his colleague Dana Rohrbacher, who came right out and said The Dinner Party was 'pornographic,' which is what Parris's comments about 'offensiveness' probably implied” (220).

"We now have this pornographic art," railed Dornan, "I mean, three-dimensional ceramic art of 39 women's vaginal areas, their genitalia, served up on plates." After introducing the Washington Times's distorted reports [of financial improprieties] directly into the Congressional Record, the congressman went on to make the entirely fictional statement that the piece had been "banned in art galleries around the country ... and characterized as obscene." (220)

Chicago reports several congressmen attempted to counter the charges, but the so-called Parris Amendment was passed by a large majority and the university was left to deal with a reduced budget as punishment for accepting a gift from Judy Chicago.

Later that summer, the Christian Television Network and Pat Robertson continued the smear campaign, lambasting The Dinner Party as the devil's work and labeling Chicago the Antichrist. After considerable organizational and educational effort, a committee of senators voted to restore the money cut by the Parris Amendment. But given the disagreement between the House and Senate votes, the issue went to a conference committee, which was ultimately expected to confirm the Senate committee's decision to reinstate the funding. Meanwhile, all support from the university dissolved when students called a strike due to a lack of confidence- - their own and the faculty's-in the trustees' judgment in having accepted the gift. They branded Chicago and her work "the enemy" - a move Chicago believes was deliberately calculated to manipulate the students and divide their support. Chicago was eventually forced to withdraw her offer. Later, Congressman Richardson reversed his position and read a notice of support for the work into the Congressional Record, but by then it was too late. As of 1996, the space that was to be used for the display of the work still had not been filled; the artwork, which could have been available to thousands 

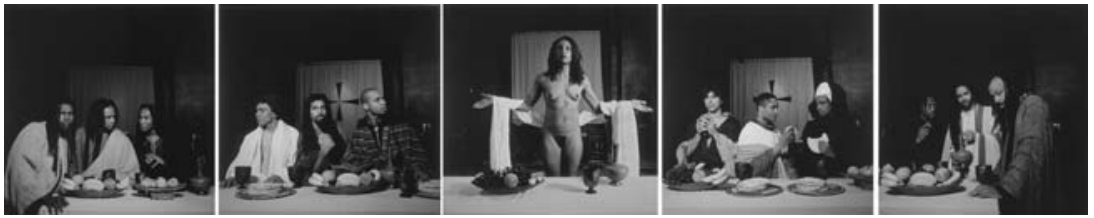

Renée Cox, Yo Mama's Last Supper (Cibachrome print), 30 × 150 in./ 76.2 × 381 cm., 1996. Courtesy Robert Miller Gallery, New York

of viewers, remained boxed up and in crates. As Lippard observed in noting the real meaning behind the iconography and content of The Dinner Party, the work was "threatening" in its "much needed historical analysis of the connections between feminism and the civil rights movement" (quoted in Chicago 1996, 222). She was not surprised that Washington, D.C., a hotbed for political debate and conservatism, was unable to open its mind to Chicago's art.

A second, more recent example (Figure 4) is the work of Renée Cox, a creative and bold photographer, who routinely uses her own body as the subject matter of her work (Cox 2001). Sometimes she also includes her son(s); in one work, she becomes an outrageous, contemporary African-American version of the religious icon, the Madonna. The danger of Cox's self-expression became all too evident early in 2001 when her work caught the attention of former mayor of New York City Rudolph Giuliani, prompting him to seek to create a censorship panel in the city to control what he called "indecedent"art. The image that antagonized him was her 1996 photographic version of Leonardo da Vinci's familiar Last Supper, entitled Yo Mama's Last Supper, in which she was pictured nude with twelve clothed black men. The disapproving tone of criticism was evident in newspaper articles written about the photo, in which she was accused of self-worship and vicious anti-Catholicism.

In her provocative work, Cox defied the age-old tradition of men defining women. She expressed her own views of sexuality and religious taboos on several levels. First, unlike The Dinner Party, which presented viewers with symbolic vaginas functioning as generic representations of female sexuality, she intimately personalized the image. Second, she did not displace the iconography onto ceramic plates but rather photographed her own body. Third, she assumed the daunting task - as a woman and African American_of posing as Christ. This angered Christians, particularly Catholics, who followed Giuliani's unwillingness to grant aesthetic autonomy to a work of art that satirized religion. Fourth, the act of exhibiting her work in the Brooklyn Museum of Art signaled a widespread political gesture; she issued an invitation to viewers and nonviewers alike to see the image and judge for themselves. She challenged them to think about the white, male-dominated history of the Catholic Church and its production of female images, and to consider alternatives that would grant women more 


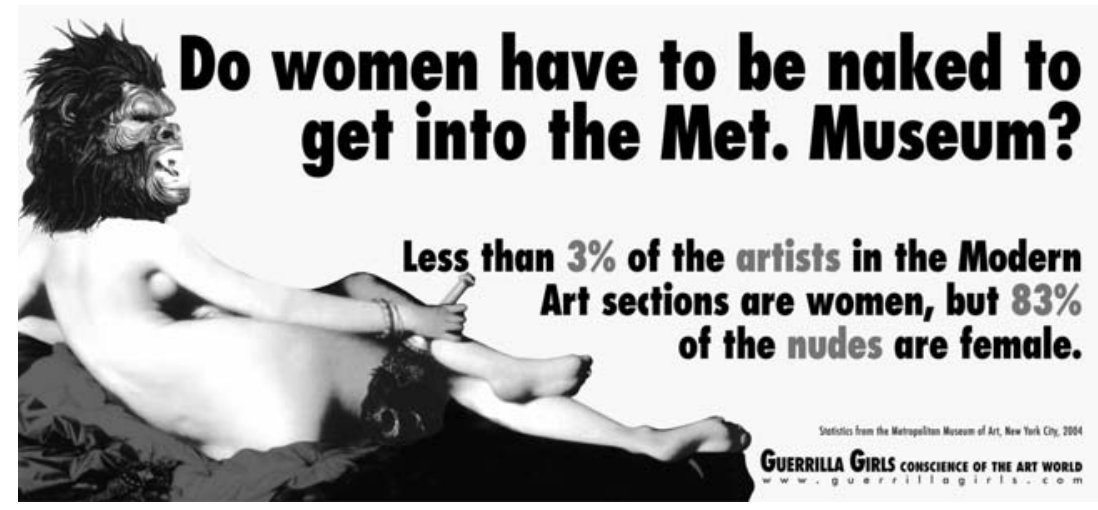

Guerrilla Girls, Do Women Have to be Naked to Get into the Met. Museum? Copyright (C) 1989, 1995.

equality and recognition. Cox's message was broader than just the defiance of the New York artworld. By depicting herself nude, in all her bodily beauty and bravura, Cox brought attention to the female body and its attendant sexuality, all the more blatantly within a religious framework and a conservative political climate. It is easy to see why Giuliani sought an institutional structure to ban future work like hers and to silence the output of other women who might follow suit. Threatened by the power he saw on view, he exercised his authority to establish a censorship board to control artistic indecency.

\section{Building FAEs to Understand Feminist Art, in Particular, FVPs}

As these two examples demonstrate, women still struggle to achieve recognition and respect comparable to men's within the artworld and the broader sociopolitical context. In contrast to this dispiriting pattern, recall the uplifting model of activism (cited earlier) that is making a difference, the Guerilla Girls, whose posters have helped raise the visibility of women artists and their status in the artworld.

In particular, consider one of their best known posters (Figure 5), which asks, "Do Women Have to be Naked to Get into the Met[ropolitan] Museum?" an imitation of a well-known "masterpiece" painted in 1814 by Jean-AugusteDominique Ingres entitled La Grande Odalisque. ${ }^{19}$ The additional prop of a gorilla mask covers the face of the original odalisque, making reference to the Girls' activist street behavior-posting posters and giving lecturesanonymously, secretly, and always in gorilla costume.

Like Judy Chicago and Renée Cox, who created art that embodies female identity and power, the Guerilla Girls devised a coordinated, highly visible, and 
popular method to subvert the status quo, disrupt the hierarchy of male power and star making, and circumvent the media-saturated gallery and museum structure in order to afford more opportunities for women. Their intent was to undermine the oppressive practices of the artworld, to educate the public about the plight of women, and to combat ignorance about women's art. In addition to sharing a common social content and a feminist message, there is a shared formal approach as well. What is common to all three is the stylistic use of FVP. I offer a workable definition of the term here. A feminist parody is:

1. a feminist satire, and

2. a complex imitation of an original work of art by a male artist.

A feminist satire is a work of art that expresses and values a woman's point of view as it makes fun of prevailing artistic conventions and societal norms established by men. A simple imitation is an imitation in which an artist copies the same style as an original work of art, without implicitly providing some sort of commentary on the original. A complex imitation is an imitation in which an artist copies the style of an original work of art, resulting in either an implicit or explicit commentary on the original. Needless to say, the distinctions between simple and complex imitations, as well as the identification of a visual work of art as satire or parody rest on artistic intentions and a reliable knowledge of them. Such knowledge, informed by a pro-female ideology of integrity, strength, freedom, and self-empowerment, is what constitutes a feminist art epistemology. Many types of knowledge can inform a general understanding and appreciation of art, but FAEs are crucial to a full understanding and appreciation of feminist art, as intended by its creators.

What information functions as an FAE that allows us to more fully experience Chicago's The Dinner Party? To define the work as a parody is to highlight its imitative format that copies yet alters the standard Last Supper by Leonardo da Vinci, completed in 1497. The Dinner Party showcases all women instead of men; the table is triangular and nonhierarchical instead of a standard horizontal table with Christ at the center. Chicago's commemoration focuses on thirty-nine artists instead of twelve apostles; on women's autonomous accomplishments instead of men's following of Christ; on the rise of female power instead of maleorganized religion and codification of misogynistic dogma. Her iconography is graphic and focused on women's physical and psychological power in contrast to the depiction of specific men and their leader, the all-powerful Christ and God, his father. Her focus is new and creative; she offers us plates, china painting, embroidered runners, and the names of an additional 999 accomplished women inscribed on the floor. Her version stands in stark contrast to those created by male artists who have typically depicted the final gathering of Christ as an exclusive soiree: no women allowed-except to serve men. She intentionally 
departs from the centuries-old format yet retains some recognizable features in order to present a positively charged energy designed to undermine the male power structure that sought to suppress women's voices and ambitions. Even her act of creation is a gesture of defiance, since there was no tradition, in 1979, of female artists painting Last Supper scenes, especially toward the goal of empowering women. Her work seeks to undo the grip of the art-historical canon on the minds of art viewers and to present an alternative worldview.

Of course, Cox's work is also derived from da Vinci's Last Supper, even more strictly so. What knowledge constitutes an appropriate FAE for understanding her work? Retaining the original horizontal format, Cox occupies the center of the space: a naked Christ surrounded by black male disciples. As a Catholic, she calls attention to a religious hierarchy from which she feels excluded, as both a woman and a black. Like The Dinner Party, Yo Mama's Last Supper not only satirizes but also subverts the dominant order of white male privilege within the artworld and world of religion. Both Cox and Chicago seek to redefine 'woman' as an autonomous, active agent who functions in rebellion to the imposed patriarchy. The fierce backlash to their message of sexuality and empowerment by nervous, conservative politicians shows the personal and political risk involved in creating effective satire and parody (FVPs).

When the Guerilla Girls parody Ingres's painting in order to question the number of women depicted nude in the Metropolitan Museum, information within the FAE functions to augment our experience of a mask-wearing woman. As in the case of joke telling and other forms of humor that have long been the province of men, ${ }^{20}$ special information is needed to get the meaning, to understand the parody. In disparaging the stereotype of the humorless woman, the Guerilla Girls rebel with a female point of view that has been key to their widespread appeal and success. These artists not only invoke a specialized knowledge of art history, artistic conventions, religious doctrine, and philosophical teaching about women that has served for centuries to relegate women to secondary status, but they also provide an imaginative re-creation of the original artwork that presumes shared knowledge and insight. Without an informative FAE, understanding is difficult and full appreciation-artistic or ideological—is impossible.

For this feminist political strategy to work, two steps are essential: art viewers must recognize that (1) original works of art are being used as intentional targets of parody, and (2) the target is ridiculed by the parodist for the dual purposes of subverting the current power structure and advancing change for women. If a viewer fails with (1), she lacks a mental image of the original work of art and cannot compare it to the parody. If a viewer fails with (2), she risks misinterpreting the artist's meaning and judging the work erroneously. For instance, one common mode of misinterpretation is to assume that the female artist's imitation of an original work of art created by a male artist is actually a positive 
tribute or homage to the original. Given that visual images can lead to a variety of readings, parodies can be read mistakenly as acts of adulation-imitation as the sincerest form of flattery. To foreclose on this misreading, condition (1) of the definition of feminist visual parody requires that it be a subspecies of satire. Satires are typically critical, sarcastic, and leave little room for ambiguity or misinterpretation.

FAEs can take a variety of forms. As there is no one type of feminism, there is no one FAE that one is required to adopt. A variety of interpretive strategies have been designed by feminist theorists in the arts, often originating within literary circles. Some focus on the political, some on the psychoanalytic, and some on uniquely postmodern facets of art. Also, it is quite conceivable that FAEs of the 1970s differ from those of the 1980s, the 1990s, and now. FAEs may even vary within a decade, within a single year, or within a particular culture, population, or geographic location, for example, a New York-centered FAE versus a West Coast FAE or a European FAE versus an American one. Several FAEs might be utilized to assess a work of art; and some may overlap in approach. The cases of Chicago and Cox demonstrate that a feminist viewpoint on religion, philosophy, and the history of art can all, simultaneously, enter into play. Moreover, FAEs need not be restricted only to feminist works of art. In the early days of the feminist art movement, FAEs were initially designed to reinterpret and reevaluate the canon of art male artists produced. A feminist point of view was utilized to advance arguments about the exploitative nature of representations of women's bodies; for example, Laura Mulvey's revolutionary theory of the male gaze gave rise to bell hooks's racialized analysis of how men depict women. ${ }^{21}$ Finally, FAEs may be somewhat contradictory. Just as there are opposing viewpoints on the nature of male-created pornography-some feminists in favor of unsanctioned freedom of expression regardless of content; some feminists opposed based on the denigration of women by means of visual imagery - there will inevitably be a variety of feminist viewpoints of feminist art that are not in agreement. This is particularly true in cases where the female body is represented nude (consider Vanessa Beecroft's staging of nude women in stiletto heels in the lobby of the Guggenheim Museum as a live art performance) or in seductive poses that resemble standard porn (some of the work of photographer Cindy Sherman or some of the "bimbo art" of Lisa Yuskavage). ${ }^{22}$

We live in an era that is sometimes referred to in the artworld as post-postmodernism; in this context, generational differences can often become the basis of dissimilar opinions, with "post-feminists" defending the dissemination of imagery of women's bodies squarely within the male paradigms of sexism-for instance, the recent pinup poses of female Olympic athletes in magazines like Playboy, FHM, and Maxim. Some younger women argue that pictures of themselves nude celebrate their independence and athletic abilities; they have earned the right to choose, on their own, where and how they appear in the media. 


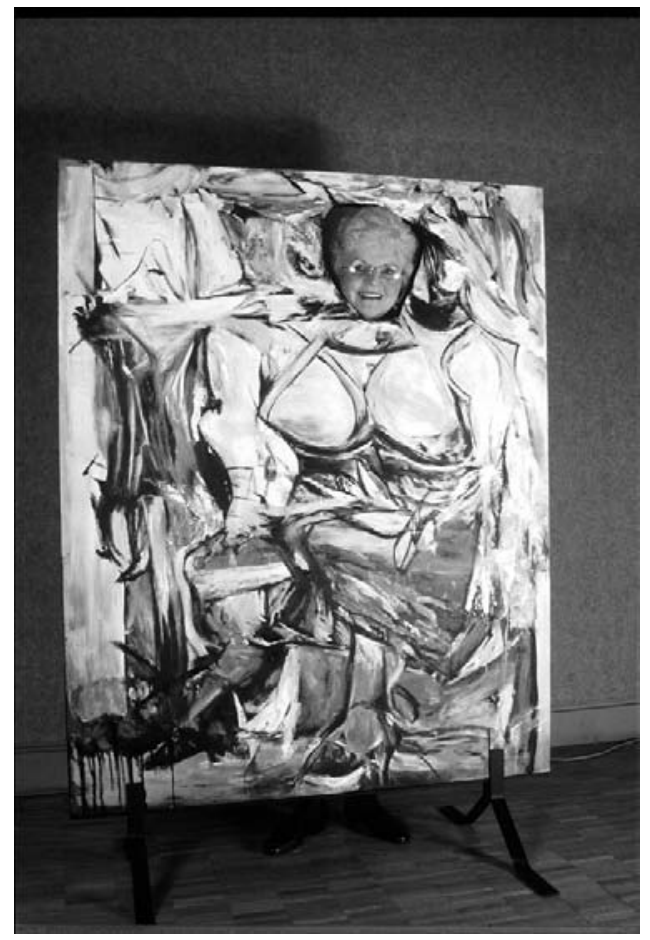

Caption: Peg Brand, second version of Wilma de Kooning's Woman I $a$ with person posing in the painting (oil on foam board) $473 / 8 \times 593 / 8 \times 1 \frac{1}{1 / 2}$ in., 1999. Collection of the artist.

Others worry that a standard pornographic venue like Playboy peddles women's bodies to male viewers who care little about how high women jump or how fast they run. Amazingly, this was such an important topic the first weekend of the 2004 Olympics that the New York Times published two articles in two days, the first on the front page of the newspaper simply reporting the phenomenon, and a second - the next day — in the Style section a defense of the athletes' actions written by female athlete Diana Nyad. ${ }^{23}$ Nyad failed to mention, however, that five athletes posed nude and that U.S. Olympic high jumper Amy Acuff was writing about her Olympic experiences in a diary online at www.playboy.com. (Acuff claims to have collaborated with Playboy for the money.)

Finally, let us return to the painting cited at the beginning of this essay, entitled Wilma de Kooning's Woman Ia (Figure 6), this time with a person posed in the painting. It should be clear at this point in the discussion that without an informative FAE, a viewer would be hard pressed to interpret adequately the art object before her. The work consists of oil paint on foam board (with a thickness of one inch and a half) that measures four by five feet. It is freestanding; it does not hang on the wall but rather rests in a wrought iron stand that allows the painting to function as a three-dimensional sculpture, which viewers can walk around. In addition, the painting offers a participatory experience; the 
hole that is cut where the menacing face would appear provides the opportunity for a viewer to place her or his face within the space and to pose as if she or he were the woman posing for the original painter, Willem de Kooning. Most people, particularly older women, find this experience inviting and playful; they often ask to pose more than once. At an art opening where the painting was displayed for the first time, I set up two cameras: one to catch a likeness of the poser on slide film for future use an illustration for written work such as this essay, and another on Polaroid, designed for the poser to take away as a souvenir. Men were more skeptical than women upon first encountering the invitation, but often posed as well, with great delight. Posers may enjoy the activity at a simplistic level, much as they would enjoy posing in an advertising board at an amusement park, but the real meaning of the work of art is undeniably contained, in part, in the background knowledge specific to the artwork parodied, namely, within the FAE.

In comparing the parody to the original, one is clearly an imitation of the other. With its face cut out, the copy is unambiguously satiric in critical intent. It is also a complex imitation in which an implicit or explicit commentary on the original offers one artist's point of view: a criticism of the artist for portraying the woman in Woman I in such a negative way. The use of "Wilma de Kooning" as the purported artist of the painting seeks to attribute the parody to a fictional woman, perhaps the wife of the original artist, Willem. Willem de Kooning himself changed his interpretation of the work after harsh criticism, eventually recasting his initial enthusiasm-"I like beautiful women. In the flesh; even models in magazines"- to embarrassed disapproval- "In a way, I feel the Women of the 50's were a failure. I see the horror in them now, but I didn't mean it. I wanted them to be funny and not to look sad and down-trodden... so I made them satiric and monstrous, like sibyls" (Prather 1994, 132).

And why is the image reversed? Additional background information locates a reproduction of the original de Kooning painting in a textbook entitled Art of the Western World: From Ancient Greece to Post-Modernism (Wood, Cole, and Gealt 1989, 306). My painting is one of a series of twelve, all of which are based on reproductions in this text. Initially appearing to be a standard and noncontroversial text, Art of the Western World is actually an example of institutionalized knowledge that seeks to marginalize women's achievements under the guise of teaching an objective appreciation for "artistic value." Only a handful of women are included among three hundred artists total. In addition, the authors' biases, clearly presented in the preface, set the tone for the chapters that follow. Asserting that cultural relativism is "naïve and misguided," the authors claim that an openness to cultural differences "spurns qualitative judgments" and "has recently obscured and downgraded the brilliance of Western art" (Wood, Cole, and Gealt 1989, vii). The text, in effect, functions as a stalwart barrier 
to feminist evaluations of art, feminist art, and indirectly, the use of FAEs to interpret and assess art. As the artist of the feminist artwork that parodies de Kooning, I found it ironic that these evaluators-who so eagerly dismiss points of view inconsistent with their own - mistakenly reproduced the original painting by de Kooning backward. I hope that this additional knowledge adds to the humor of the imitation, particularly since at the time of this writing, coauthor Bruce Cole currently serves as Chairman of the National Endowment for the Humanities, appointed by President George W. Bush and revered by academics for his impeccable scholarship and art-historical standards. The fact that his text reverses de Kooning's Woman I serves as a poignant reminder that not all so-called experts of the art-historical canon are always correct, in spite of their privileged position to adjudicate. Furthermore, they should not be immune to criticism. Political agendas, particularly antifemale ones, can surface in any reputable publication. Careful study reveals that any text, however objective it appears at first glance, can promote institutionalized patriarchal knowledge that either omits women's accomplishments or seeks to maintain ignorance about them. The antidote to biased art history is the inclusion of more work by women artists, set in the context of appropriate FAEs that serve to inform viewers of the full meaning of the works of art.

Feminist art epistemologies greatly aid the understanding of feminist art, particularly when they serve to illuminate the hidden meanings of an artist's intent. The success of the imagery produced by Judy Chicago, Renée Cox, the Guerrilla Girls, and my own example of Wilma de Kooning's Woman I $a$-all feminist visual parodies-depends upon a viewer's recognition of the original work of art created by a male artist and the realization of the parodist's intent to ridicule and satirize. Such recognition and realization constitute the knowledge of a well-(in)formed FAE. Without it, misinterpretation is possible and viewers may fail to experience and enjoy a full and rewarding encounter with a provocative and subversive work of art.

Once feminists welcome and advocate the intent of FVPs, they can more clearly value the role that women artists have played in overturning the longstanding institutionalization of ignorance about women and their accomplishments within the artworld. Far from complete, the transition to parity within the artworld is still under way. As the Guerilla Girls have asked, who knows what power bitches, bimbos, and ballbreakers might eventually hold? There's only one way to find out. I invite everyone to enjoy rebellious feminist challenges and changes to the artworld, together, as we parody for parity. 


\section{Notes}

1. Willem de Kooning's painting, Woman I (oil on canvas, $757 / 8 \times 58$ in.), dates from 1952 and is on view at the Museum of Modern Art (see http://www.moma.org/ collection). My copy is identical except for a hole cut in the panel board where the head appears.

2. "The artworld" is a term philosopher and art critic Arthur Danto coined to designate those people whose business, beginning in the 1950s and 1960s, was to produce, market, and write about art. New York City is still considered by many as the center of the intelligentsia and avant garde of the artworld (Danto 1964).

3. Against the philosophical stance of anti-intentionalism, I argue elsewhere for the importance of recognizing artists' intentions, particularly since women artists' works are often deliberately ambiguous. Male critics, invoking critical authority, can unfairly misinterpret and devalue such work. See Brand 2006.

4. Feminist art theorists have noted the lack of a comparable term for women as they chronicled the severe limitations on women's creative possibilities; see, for example, Parker and Pollock 1981.

5. Linda Nochlin's famous 1971 essay, "Why Have There Been No Great Women Artists?" launched the inquiry into the challenges faced by women in art (Nochlin 1971/1988). Aruna D'Souza edited a follow-up volume of essays entitled Self and History: A Tribute to Linda Nochlin (2001).

6. Early influential texts on women artists include Tufts 1974; Greer 1979; and Harris and Nochlin 1981. More recent volumes are Chadwick 2002; and Chicago and Lucie-Smith 1999.

7. One need not consult only feminist critiques of art history for excellent examples; see Tuana 1993.

8. These messages can take many forms, for example, the professor of studio art who cites only male artists as paradigms for student improvement or who derides an artwork during class critique as "weak" or "feminine." An art history professor may choose an introductory text that includes only a few token women among hundreds of male artists or may deny permission to a doctoral student who seeks to write a dissertation on gender differences in artistic creativity. A philosophy professor might insist on the study of the history of aesthetics with no inclusion of contemporary feminist challenges to the exclusivity of the white, educated man of taste or he may replicate the exclusivity of the art historical canon by teaching that paradigmatic aesthetic experiences are the result of viewing only "masterpieces." In all these cases, one can only conclude that the goal of the authority figure is to maintain the long-standing and established practice of promoting and maintaining ignorance about women's accomplishments.

9. For example, in a review by Holland Cotter (2004, B27, B29) of five museums and numerous galleries focusing on African-American art and culture, only one woman is mentioned out of fourteen artists total.

10. In one case alone, critic Michael Kimmelman (2004) invoked twelve men to elevate the status of artist Olafur Eliasson. Comparisons were made between lesserknown Eliasson and noted playwrights Henrik Ibsen and August Strindberg, artist Laszlo Moholy-Nagy, painter and inventor of the daguerreotype Louis Jacques Daguerre, 
engineer-theorist Buckminster Fuller, and philosopher Henri Bergson. In another case, there is mention of the artist shaking hands with Jerry Saltz, renowned art critic of the Village Voice, a big event in the life of an unknown artist whose artwork gained notice because he sold a sand castle for $\$ 5500$ (DeSilverio 2004).

11. In her case, the references are to critic and novelist C. S. Lewis, painters Michelangelo and Pablo Picasso, and contemporary video artist Matthew Barney (creator of the recent Cremaster cycle, a series of eight videos hyped as a work of genius in today's artworld) (Bard 2004).

12. In the case of Jeff Koons, the artist has posed with his former wife, a porn star (and ex-member of the Italian parliament) known as Cicciolina, engaged in explicitly sexual behavior. As recently as August 26, 2005, New York Times art critic Ken Johnson cites Picabia and Ramos as "godfathers of an enduring trend that finds inspiration in popular erotica and pornography." 13. Fewer than two years after receiving his MFA from Yale University, Barney was pictured on the cover of Artforum (September 2002).

14. In an online article, the author cites the Kunstkompass (Art Compass), "an annual ranking [since the 1970s] of the 100 biggest living artists compiled by the German business magazine, Capital," which shows that only twenty of the 100 (ten of whom are in their thirties) are women. Monetarily, "women get half as much as men." See Greg. org, "Your Women, How Much for Your Women?” http://greg.org/archive/2005/04/30/ your_women_how_much_for_your_women.html (accessed March 2, 2005).

15. Duncan Bartlett, "Botox Injections Grow in Popularity," BBC online report from 3/12/02 at http://news.bbc.co.uk/1/hi/business/1868587.stm (accessed March 2, 2005); see also "Overview of the 2002 U.S. Cosmetic Market," http://www.cosmeticmarket. com/overview02final.html (accessed March 2, 2005).

16. The Guerilla Girls website is a playful compendium of research, online chatter, and paraphernalia for sale (www.guerillagirls.com). Their publications include Confessions of the Guerilla Girls (1995), which chronicled their founding and first ten years; The Guerilla Girls' Bedside Companion to the History of Western Art (1998), which critiqued the "stale, male, pale, Yale" perspective on art history; Bitches, Bimbos, and Ballbreakers: The Guerrilla Girls' Illustrated Guide to Female Stereotypes (2003); and, most recently, The Guerilla Girls' Art Museum Activity Book (2004). For a review of their success, see Hoban 2004.

17. For an overview and details of specific plates, see Chicago's website http://www. throughtheflower.org. See also Chicago 1979, 1980, and the volume coinciding with the 1996 commemorative exhibition at the University of California, Los Angeles, Armand Hammer Museum, Chicago, 1996.

18. According to a 2004 newsletter from Through the Flower, Chicago's nonprofit organization preserving the legacy of her work, The Dinner Party will open again in early 2007 at Brooklyn Museum's Sackler Center for Feminist Art. Elizabeth A. Sackler has provided funds for both the renovation of museum space and the first curator of feminist art ever hired by a museum. The center will also focus on feminist art and pedagogy.

19. The original oil painting, entitled La Grande Odalisque (91 × $162 \mathrm{~cm}),$.1814 , is by Jean-Auguste-Dominique Ingres and is located in the Louvre Museum, Paris, France. See http://cartelfr.louvre.fr.

20. No women theorists are cited in Morreall 1987. 
21. See Mulvey 1989, which was inspired by King Vidor's Duel in the Sun (1946) and hooks 1992.

22. See Beecroft 2000; Sherman 2004; Jenkins 2004; and Siegel 2000.

23. The first article was written by Joe Drape, "Olympians Strike Pinup Pose, and Avoid Setting off a Fuss" (2004); the second, by Diana Nyad, was entitled, "The Rise of the Buff Bunny" (2004). The New York Times, August 15, 2004. Nyad holds the world record for the longest unaided ocean swim in history for both men and women, 102.5 miles from the Bahamas to Florida.

\section{REFERENCES}

Allen, Greg. 2005. The X factor. New York Times, May 1.

Bard, Elizabeth. 2004. A video game with awe as its quest. New York Times, March 21. Beecroft, Vanessa. 2000. Vb 08-36: Vanessa Beecroft, performances. Germany: Cantz Editions.

Brand, Peg. 2006. Enhancing artistic presence through contemplative contextual criticism. In Presence, ed. Julien Robson. Louisville, Ky.: Speed Art Museum.

Chadwick, Whitney, ed. 2002. Women, art, and society. $3^{\text {rd }}$ ed. London: Thames and Hudson.

Chicago, Judy. 1979. The Dinner Party: A symbol of our heritage. Garden City, N.Y.: Anchor Books/Doubleday.

1988. Embroidering our heritage: The Dinner Party needlework. Garden City, N.Y.: Anchor Books/Doubleday.

1996. The Dinner Party. New York: Penguin Books.

-, and Edward Lucie Smith. 1999. Women and art: Contested territory. New York: Watson-Guptill Publications.

Cotter, Holland. 2004. Black comes in many shadings. New York Times, August 13.

Cox, Renée. 2001. Renée Cox: American family. New York: Robert Millery Gallery.

Danto, Arthur C. 1964. The artistic enfranchisement of real objects: The artworld. Journal of Philosophy 61 (19): 571-84.

DeSilverio, Victoria. 2004. New artist in town. New York Times, March 21.

Drape, Joe. 2004. Olympians strike pinup pose, and avoid setting off a fuss. New York Times, August 14.

D'Souza, Aruna, ed. 2001. Self and history: A tribute to Linda Nochlin. London: Thames and Hudson.

Greer, Germaine. 1979. The obstacle race. New York: Farrar Straus Giroux.

Guerilla Girls. 1995. Confessions of the Guerilla Girls. New York: HarperPerennial.

1998. The Guerilla Girls' bedside companion to the history of Western art. New York: Penguin Books.

2003. Bitches, bimbos, and ballbreakers: The Guerrilla Girls' illustrated guide to female stereotypes. New York: Penguin Books.

. 2004. The Guerilla Girls' art museum activity book. New York: Printed Matter, Inc. 
Harris, Ann Sutherland, and Linda Nochlin. 1981. Women artists: 1550-1950. New York: Alfred A. Knopf.

Hoban, Phoebe. 2004. Masks still in place, but firmly in the mainstream. New York Times, January 4.

hooks, bell. 1992. The oppositional gaze. In Black looks: Race and representation. Boston: South End Press.

Jenkins, Tamara. 2004. Lisa Yuskavage: Small paintings, 1993-2004. New York: Harry N. Abrams.

Kimmelman, Michael. 2003. With barbed wit aforethought: John Currin up till now. New York Times, November 21.

- 2004. The sun sets at the Tate Modern. New York Times, March 21.

Lippard, Lucy R. 1976. From the center: Essays on women's art. New York: Dutton.

Morreall, John. 1987. The philosophy of laughter and humor. New York: SUNY Press.

Mulvey, Laura. 1989. Visual and other pleasures. Bloomington: Indiana University Press.

Nochlin, Linda. 1971/1988. Why have there been no great women artists? In Women, art, and power and other essays. New York: Harper and Row, 1988.

Nyad, Diana. 2004. The rise of the buff bunny. New York Times, August 15.

Parker, Rozsika, and Griselda Pollock. 1981. Old mistresses: Women, art, and ideology. New York: Pantheon Books.

Prather, Marla. 1994. Willem de Kooning: Paintings. Washington, D.C.: National Gallery of Art; New Haven, Conn.: Yale University Press.

Sherman, Cindy. 2004. Cindy Sherman: Centerfolds. New York: Skarstedt Fine Art.

Siegel, Katy. 2000. Lisa Yuskavage by Lisa Yuskavage. Philadelphia: University of Pennsylvania Institute of Contemporary Art.

Solomon, Deborah. 2003. Mr. Bodacious: John Currin paints outrageous pictures of women and an even more outrageous portrait of art history, the art world, and himself. New York Times Magazine, November 16.

Tuana, Nancy. 1993. The less noble sex: Scientific, religious, and philosophical conceptions of woman's nature. Bloomington: Indiana University Press.

Tufts, Eleanor. 1974. Our hidden heritage: Five centuries of women artists. New York: Paddington Press.

Wood, Michael, Bruce Cole, and Adelheid Gealt. 1989. Art of the Western world: From ancient Greece to post-modernism. New York: Simon \& Schuster. 